\title{
Implementasi Undang-Undang Nomor 36 Tahun 2014 tentangTenaga Kesehatan dalam Pemberian Pelayanan pada Pasien di Puskesmas Bajoe Kecamatan Tanete Riattang Timur Kabupaten Bone
}

\author{
Wahyuni \\ Institut Agama Islam Negeri (IAIN) Bone \\ wahyunihtniainbone@gmail.com
}

\begin{abstract}
Abstrak
Penelitian ini bertujuan untuk mengetahui mengenai implementasiUndang-UndangNomor 36 Tahun 2014 tentang Tenaga Kesehatan terhadap pemberian pelayanan pada pasien dan kendala dalam pemberian pelayanan kesehatan oleh tenaga kesehatan terhadap pasiendi Puskesmas Bajoe Kecamatan Tanete Riattang Timur Kabupaten Bone. Data yang diperoleh diolah dengan menggunakan metode analisis data kualitatif untuk menganalisis terkait pemberian pelayanan kesehatan oleh tenaga kesehatan terhadap pasien di Puskesmas BajoeKecamatan Tanete Riattang Timur Kabupaten Bone. Hasil penelitian ini menunjukkan bahwa tenaga kesehatan dalam memberikan pelayanan kesehatan kepada pasien di Puskesmas BajoeKecamatanTanete Riattang Timur Kabupaten Bone sudahberjalan denganbaik, namun belum terlaksana dengans empurna.Hal tersebut terjadi karena adanya kekurangan atau ketidaknyamanan yang diterima oleh pasien dalam memperoleh pelayanan kesehatan oleh tenaga kesehatan.Pernyataan tersebut diperoleh dari tenaga kesehatan yakni dokter, bidan, dan apoteker melalui kuesioner serta wawancara oleh pasien di Puskesmas Bajoe KecamatanTanete Riattang TimurKabupaten Bone.
\end{abstract}

\section{Kata Kunci : Implementasi Undang-Undang Nomor 36 Tahun 2014, Tenaga Kesehatan, Pelayanan pada Pasien di Puskesmas Bajoe Kecamatan Tanete Riattang Timur Kabupaten Bone}

\section{PENDAHULUAN}

Sejarah perkembangan kesehatan masyarakat di Indonesia dimulai sejak pemerintahan Belanda pada abad ke-16. Kesehatan masyarakat di Indonesia pada waktu itu dimulai dengan upaya pemberantasan cacar dan kolera yang sangat ditakuti masyarakat. ${ }^{164}$ \footnotetext{
2014), h. 9.

${ }^{164}$ Adik Wibowo, Kesehatan Masyarakat Indonesia, Ed. 1 (Cet. 1; Jakarta: Rajawali Pers, Jurnal Al-Dustur; VOLUME 2 NO 1, JUNI 2019
} 
Kesehatan merupakan salah satu unsur kesejahteraan yang harus diwujudkan sesuai dengan cita-cita bangsa Indonesia sebagaimana dimaksud dalam Pancasila dan Pembukaan Undang-Undang Dasar Negara Republik Indonesia Tahun 1945. ${ }^{165}$

Menurut Undang-Undang Nomor 36 Tahun 2009 tentang Kesehatan Pasal 1 ayat 1 bahwa kesehatan adalah keadaan sehat, baik secara fisik, mental, spiritual maupun sosial yang memungkinkan setiap orang untuk hidup produktif secara sosial dan ekonomis. ${ }^{166}$

Hidup sehat untuk semua orang merupakan hak asasi manusia dan hal ini telah diakui oleh semua negara, termasuk Indonesia. Undang-Undang Dasar 1945 telah memuat hal ini pada:

1. Pasal 28 yang berbunyi bahwa kemerdekaan berserikat dan berkumpul, mengeluarkan pikiran dengan lisan dan tulisan dan sebagainya ditetapkan dengan undang-undang. ${ }^{167}$

2. Pasal 34 ayat 1 yang berbunyi bahwa negara bertanggung jawab atas penyediaan fasilitas pelayanan kesehatan dan fasilitas pelayanan umum yang layak. ${ }^{168}$

Setiap upaya kesehatan harus berlandaskan perikemanusiaan yang dijiwai, digerakkan, dan dikendalikan oleh keimanan dan ketaqwaan terhadap Tuhan Yang Maha Esa. Tenaga kesehatan perlu berbudi luhur memegang teguh etika profesi.

Sebagaimana firman Allah swt. dalam QS. Al-Maidah (5): 2

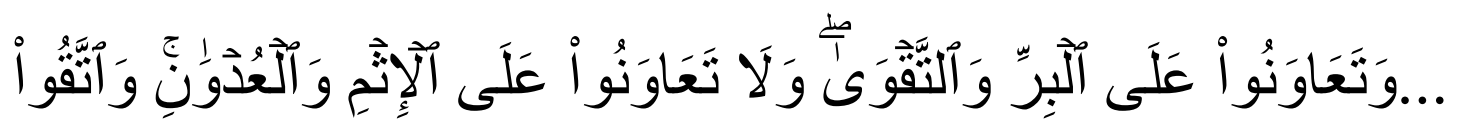

${ }^{165}$ Danny Wiradharma, Penuntun Kuliah Hukum Kedokteran, Ed. 1 (Cet 1; Jakarta: Anggota IKAPI, 2010), h. 203. 1.

${ }^{166}$ Republik Indonesia, Undang-Undang Nomor 36 Tahun 2009 tentang Kesehatan, Pasal 1 ayat

${ }^{167}$ Republik Indonesia, Undang-Undang Dasar Republik Indonesia Tahun 1945, Pasal 28.

${ }^{168}$ Republik Indonesia, Undang-Undang Dasar Republik Indonesia Tahun 1945, Pasal 34 ayat 1. 


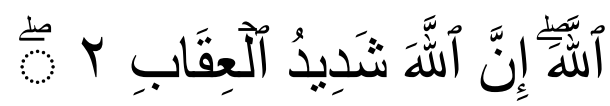

Terjemahnya:

...Dan tolong menolonglah kamu dalam mengerjakan kebajikan dan takwa, dan jangan tolong menolong dalam berbuat dosa dan pelanggaran. Dan bertakwalah kamu kepada Allah, sesungguhnya Allah amat berat siksa-Nya. ${ }^{169}$

Bahwa dalam agama islam mewajibkan untuk menolong pasien tanpa melihat kondisi keuangan dan kemampuan membayar biaya tindakan medis. Seorang pelayan kesehatan yang mana akan menjadi ladang pahala ketika menerapkan nilai-nilai di dalam pelayanannya.

Rasulullah SAW bersabda:

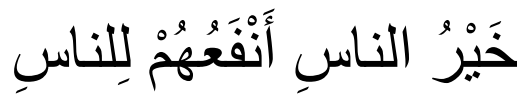

Artinya:

"Sebaik-baiknya manusia adalah yang paling bermanfaat bagi manusia" (HR.

Ahmad, ath-Thabrani, ad-Daruqutni. Hadist ini dihasankan oleh al-Albanidi dalam Shahihul Jami’ no: 3289$).{ }^{170}$

Menjadi pribadi yang bermanfaat adalah salah satu karakter yang harus dimiliki oleh setiap muslim. Setiap muslim diperintahkan untuk memberikan manfaat bagi orang lain. Memberikan manfaat kepada orang lain, maka manfaatnya akan kembali untuk kebaikan diri kita sendiri.

Dalam hal kesehatan setiap orang mempunyai hak yang sama dalam memperoleh derajat kesehatan yang setinggi-tingginya, tanpa memandang suku, golongan, agama, dan status sosialnya.

\footnotetext{
${ }^{169}$ Departemen Agama RI, Al-Qur'an dan Terjemahnya, Jilid V (Cet. III; Jakarta: Lembaga Percetakan al-Qur'an Departemen Agama, 2009), h. 157.

${ }^{170} \mathrm{HR}$. Ahmad, ath-Thabrani, ad-Daruqutni. Hadist ini dihasankan oleh al-Albanidi dalam Shahihul Jami’ no: 3289. 
Akan tetapi dengan adanya kasus yang sedang beredar saat ini sangat berolak belakang dengan penjelasan ayat dan hadis tersebut. Tragedi Kematian bayi Tiara Debora Simanjorang sejatinya hanyalah puncak gunug es ditengah lautan karena sudah menjadi rahasia umum bahwa orang miskin di negeri ini harus berjuang mati-matian untuk mendapatkan pelayanan kesehatan di RS.

Kematian bayi Debora telah menyulut amarah publik hanya karena kekurangan uang muka atau uang DP senilai 6 juta rupiah, nyawa bayi 4 bulan tersebut harus melayang di ruang IGD RS mitra keluarga Kalideres bahkan kartu BPJS saja sebagai jaminan ternyata tak dianggap. Orang tua Debora sejatinya bukanlah orang miskin papan, mereka bisa menyediakan uang 5 juta sebagai bayaran awal agar Debora bisa di rawat di ruang PICU, namun 5 juta saja ternyata tak cukup karena minimal yang harus dibayar yakni 11 juta rupiah. Padahal tanpa uang muka pun di RS seharusnya membawa Debora ke ruang PICU karena sifatnya gawat darurat. ${ }^{171}$

Semoga saja dengan adanya kejadian tersebut dapat memberikan pelajaran bagi kita semua yang selalu memandang sebelah mata orang lain hanya karena kekurangan yang dimilikinya, sehingga tidak akan ada lagi Debora selanjutnya.

Maka dari itu masyarakat yang berstatus pasien berhak memperoleh pelayanan kesehatan yang optimal sesuai dengan kebutuhan, baik pelayanan kesehatan dasar maupun rujukan, tanpa membedakan status sosial. Tenaga kesehatan mempunyai kewajiban untuk dapat mengendalikan dan menyempurnakan pelayanan yang disediakan kepada pasien. ${ }^{172}$

Menurut Undang-Undang Nomor 36 Tahun 2014 tentang Tenaga Kesehatan Pasal 1 ayat 1 menyatakan bahwa tenaga kesehatan adalah setiap orang yang mengabdikan diri dalam bidang kesehatan serta memiliki pengetahuan dan/ atau keterampilan melalui pendidikan di bidang kesehatan yang untuk jenis tertentu

${ }^{171}$ Chanel TV ONE, di akses pada 15 September 2017

${ }^{172}$ Tjahjono Koentjoro, Regulasi Kesehatan di Indonesia Edisi Revisi (Yogyakarta: CV Andi Offset, 2011), h. 1 
memerlukan kewenangan untuk melakukan upaya kesehatan. ${ }^{173}$

Asas pelayanan kesehatan menurut Pasal 2 Undang-Undang Nomor 36 Tahun 2014 tentang Tenaga Kesehatan adalah sebagai berikut:
a. Perikemanusiaan;
b. Manfaat;
c. Pemerataan;
d. Etika dan profesionalitas;
e. Penghormatan terhadap hak dan kewajiban;
f. Keadilan;
g. Pengabdian;
h. Norma agama; dan
i. Perlindungan. ${ }^{174}$

Tujuan pelayanan kesehatan menurut Pasal 3 Undang-Undang Nomor 36 Tahun 2014 tentang Tenaga Kesehatan adalah sebagai berikut:

a. Memenuhi kebutuhan masyarakat akan tenaga kesehatan;

b. Mendayagunakan tenaga kesehatan sesuai dengan kebutuhan masyarakat;

c. Memberikan perlindungan kepada masyarakat dalam menerima penyelenggaraan upaya kesehatan;

d. Mempertahankan dan meningkatkan mutu penyelenggaraan upaya kesehatan yang diberikan oleh tenaga kesehatan; dan

e. Memberikan kepastian hukum masyarakat dan tenaga kesehatan. ${ }^{175}$

Tenaga kesehatan memiliki peranan penting untuk meningkatkan kualitas pelayanan kesehatan yang maksimal kepada pasien agar pasien mampu untuk 1.

${ }^{173}$ Republik Indonesia, Undang-Undang Nomor 36 Tahun 2014 Tenaga Kesehatan, Pasal 1 ayat

${ }^{174}$ Republik Indonesia, Undang-Undang Nomor 36 Tahun 2014 tentang Tenaga Kesehatan, Pasal 2. Pasal 3.

${ }^{175}$ Republik Indonesia, Undang-Undang Nomor 36 Tahun 2014 tentang Tenaga Kesehatan, Jurnal Al-Dustur; VOLUME 2 NO 1, JUNI 2019 
meningkatkan kesadaran, kemauan, dan kemampuan hidup sehat sehingga akan terwujud derajat kesehatan yang setinggi-tingginya sebagai investasi bagi pembangunan sumber daya manusia yang produktif secara sosial dan ekonomi. Selain itu, penyelenggaraan upaya kesehatan harus dilakukan oleh tenaga kesehatan yang bertanggung jawab, yang memiliki etik dan moral yang tinggi, keahlian, dan kewenangan yang secara terus menerus harus ditingkatkan mutunya.

Tenaga kesehatan meliputi tenaga medis, tenaga psikologi klinis, tenaga keperawatan, tenaga kebidanan, tenaga kefarmasian, tenaga kesehatan masyarakat, tenaga kesehatan lingkungan, tenaga gizi, tenaga keterapian fisik, tenaga keteknisian medis, tenaga teknik biomedika, tenaga kesehatan tradisional, dan tenaga kesehatan lain. $^{176}$

Pemberian pelayanan kepada pasien merupakan kewajiban yang harus dilakukan oleh tenaga kesehatan tersebut khususnya:

1) Pelayanan dokter terhadap pasien masih sering terjadi keterlambatan pelayanan karena terkadang dokter datang tidak tepat waktu. Adapun waktu yang seharusnya adalah pukul 09.00 akan tetapi kenyataannya dokter terkadang datang pukul 10.00 .

2) Pelayanan bidan terhadap pasien kurang memuaskan karena seringkali terjadi kelalaian dalam pelayanan yang dilakukan oleh mahasiswa praktek lapangan tanpa ada arahan dari bidan yang bersangkutan.

3) Pelayanan apoteker terhadap pasien seringkali terjadi kehabisan persediaan obat yang dibutuhkan oleh pasien. Akan tetapi seorang apoteker tidak melakukan tindakan untuk memberitahukan kepada dokter bahwa obat yang dibutuhkan oleh pasien telah habis sehingga bisa menggantikan dengan obat lain dengan khasiat yang sama.

Pernyataan diatas berasal dari pasien yang memeriksakan diri di Puskesmas

${ }^{176}$ Republik Indonesia, Undang-Undang Nomor 36 Tahun 2014 tentang Tenaga Kesehatan, Pasal 11 ayat 1 . 
Bajoe Kecamatan Tanete Riattang Timur Kabupaten Bone. Dari pernyataan tersebut sudah jelas bahwa dari ketiga tenaga kesehatan tersebut yakni pihak dokter, bidan, dan apoteker tidak memberikan pelayanan yang baik kepada pasien sebagaimana yang diatur dalam Undang-Undang Nomor 36 Tahun 2014 tentang Tenaga Kesehatan Pasal 58 ayat 1 huruf a dan huruf e yang berbunyi:

a) Memberikan pelayanan kesehatan sesuai dengan Standar Profesi, Standar Pelayanan Profesi, Standar Prosedur Operasional, dan Etika Profesi serta kebutuhan kesehatan Penerima Pelayanan Kesehatan.

b) Merujuk Penerima Pelayanan Kesehatan ke Tenaga Kesehatan lain yang mempunyai kompetensi dan kewenangan yang sesuai. ${ }^{177}$

Tenaga kesehatan di atas sebagai salah satu komponen utama pemberi layanan kesehatan kepada pasien yang memiliki peranan penting karena terkait langsung dengan mutu pelayanan kesehatan sesuai dengan kompetensi dan pendidikan yang dimilikinya. Selain itu, tenaga kesehatan tersebut juga memiliki karakteristik yang khas dengan adanya pembenaran hukum yaitu diperkenankannya melakukan pelayanan kepada pasien dan apabila hal itu dilakukan oleh tenaga lain yang memang bukan haknya dapat digolongkan sebagai tindakan administratif. ${ }^{178}$

Selain itu menurut Undang-Undang Nomor 44 Tahun 2009 tentang Rumah Sakit menjelaskan tentang Perlindungan Hak Pasien pada Pasal 32 huruf c dan huruf e yang berbunyi:

a) Bahwa pasien harus memperoleh layanan yang manusiawi, adil, jujur, dan tanpa diskriminasi. ${ }^{179}$

\footnotetext{
${ }^{177}$ Republik Indonesia, Undang-Undang Nomor 36 Tahun 2014 tentang Tenaga Kesehatan Pasal 58 ayat 1.

${ }^{178}$ Wahidin, Pendidikan Kewarganegaraan ([t.t.]: In Media, 2015), h. 146.

${ }^{179}$ Republik Indonesia, Undang-Undang Nomor 44 Tahun 2009 tentang Rumah Sakit, Pasal 32 huruf $c$. 
b) Bahwa pasien harus memperoleh layanan yang efektif dan efisien sehingga pasien terhindar dari kerugian fisik dan materi. ${ }^{180}$

Dari pernyataan pasal di atas sangat bertolak belakang dengan realitas yang terjadi hal ini menyebabkan pasien tidak mendapatkan pelayanan yang memuaskan dari pihak puskesmas atau rumah sakit karena adanya kelalaian dari pihak dokter, bidan, dan apoteker sehingga merugikan pihak pasien. Hal tersebut diperoleh dari pernyataan masyarakat di Kelurahan Lonrae dan Kelurahan Toro selaku pasien yang memeriksakan diri di Puskesmas Kecamatan Tanete Riattang Timur Kabupaten Bone.

Penulis berharap agar supaya dengan adanya penelitian ini, dapat memperbaiki kesalahan dan kelalaian yang dilakukan oleh tenaga kesehatan tersebut dalam memberikan pelayanan kesehatan terhadap pasien baik yang disengaja ataupun tidak disengaja. Maka dari itu, penulis perlu meneliti Implementasi Undang-Undang Nomor 36 Tahun 2014 tentang Tenaga Kesehatan dalam Pemberian Pelayanan pada Pasien di Puskesmas Bajoe Kecamatan Tanete Riattang Timur Kabupaten Bone).

Berdasarkan latar belakang diatas maka penulis menarik rumusan masalah sebagai berikut Bagaimana pelayanan kesehatan menurut Undang-Undang Nomor 36 Tahun 2014 tentang Tenaga Kesehatan terhadap pemberian pelayanan pada pasien di Puskesmas Bajoe Kecamatan Tanete Riattang Timur Kabupaten Bone dan Bagaimana praktek dalam pemberian pelayanan kesehatan oleh tenaga kesehatan terhadap pasien di Puskesmas Bajoe Kecamatan Tanete Riattang Timur Kabupaten Bone menurut Undang-Undang Nomor 36 Tahun 2014 tentang Tenaga Kesehatan .

\section{TINJAUAN PUSTAKA}

Tinjauan pustaka merupakan penelaan terhadap penelitian terdahulu yang memiliki kesamaan topik dan berguna pula untuk mendapatkan gambaran bahwa huruf e.

\footnotetext{
${ }^{180}$ Republik Indoneisa, Undang-Undang Nomor 44 Tahun 2009 tentang Rumah Sakit, Pasal 32
} Jurnal Al-Dustur; VOLUME 2 NO 1, JUNI 2019 
penelitian yang dilakukan bukan merupakan plagiat.

Berdasarkan penelusuran penulis, belum ada peneliti sebelumnya yang meneliti terkait Implementasi Undang-Undang Nomor 36 Tahun 2014 tentang Tenaga Kesehatan dalam Pemberian Pelayanan pada Pasien di Puskesmas Bajoe Kecamatan Tanete Riattang Timur Kabupaten Bone. Maka dari itu penulis akan memaparkan halhal yang berkaitan penelitian terdahulu terkait dengan judul penelitian ini.

Skripsi yang disusun oleh Suci Lestari merupakan mahasiswa Universitas Islam Negeri Sunan Kalijaga Yogyakarta Fakultas Syariah dan Hukum, dengan judul Skripsi, "Perlindungan Hukum terhadap Pasien dalam Pelayanan Medis di Rumah Sakit PKU Muhammadiyah Yogyakarta”. Penelitian ini menggunakan penelitian lapangan dengan pendekatan deskriptif-analitis serta menggunakan data kepustakaan yaitu UndangUndang Dasar Republik Indonesia 1945, Kitab Undang-Undang Hukum Perdata, Undang-Undang Nomor 29 Tahun 2004 tentang Praktik Kedokteran, Undang-Undang Nomor 36 Tahun 2009 tentang Kesehatan, Undang-Undang Nomor 44 Tahun 2009 tentang Rumah Sakit, dan Undang-Undang Nomor 8 Tahun 2009 tentang Perlindungan Konsumen.

Skripsi di atas menjelaskan bagaimana sistem pelaksanaan penerapan hak pasien serta bagaimana bentuk perlindungan yang diberikan kepada pasien yang dalam hal ini Suci mengambil objek di rumah sakit PKU Muhammadiyah Yogyakarta. ${ }^{181}$

Selain itu, skripsi yang disusun oleh Maya Ruhtiani merupakan mahasiswa Universitas Jendral Soedirman Fakultas Hukum, dengan judul skripsi, "Perlindungan Pasien sebagai Konsumen Jasa dalam Pelayanan Kesehatan di Rumah Sakit Umum Daerah Tasikmalaya". Penelitian ini menggunakan metode pendekatan yuridis sosiologis atau yang sering disebut dengan pendekatan yuridis empiris serta menggunakan penelitian kualitatif untuk menghasilkan data deskriptif-analitis. Adapun

\footnotetext{
${ }^{181}$ Suci Lestari, "Perlindungan Hukum terhadap Pasien dalam Pelayanan Medis di Rumah Sakit PKU Muhammadiyah Yogyakarta" (Universitas Islam Negeri Sunan Kalijaga Yogyakarta Fakultas Syariah dan Hukum), 2015.

Jurnal Al-Dustur; VOLUME 2 NO 1, JUNI 2019
} 
bahan hukum primer yang digunakan adalah Undang-Undang Nomor 8 Tahun 1999 tentang Perlindungan Konsumen, Undang-Undang Nomor 44 Tahun 2009 tentang Rumah Sakit, Undang-Undang Nomor 29 Tahun 2004 tentang Praktik Kedokteran, Undang-Undang Nomor 36 Tahun 2009 tentang Kesehatan perubahan dari UndangUndang Nomor 23 Tahun 2002 tentang Kesehatan, Peraturan Menteri Kesehatan Nomor 585/MENKES/PER/IX/1989 tentang Persetujuan Tindakan Medik, Surat Keputusan Menteri Kesehatan Nomor 436/ MENKES/SK/VI/1993 tentang Berlakunya Standar Pelayanan di Rumah Sakit.

Skripsi di atas lebih mengarah bahwa bagaimana perlindungan hukum terhadap pasien sebagai konsumen jasa dalam pelayanan kesehatan yang dilaksanakan oleh tenaga kesehatan serta faktor-faktor apakah yang menunjang dan menghambat perlindungan hukum terhadap pasien di RSUD Tasikmalaya. Maksud dari konsumen jasa yakni pasien sebagai konsumen yang meneirma jasa atau pelayanan kesehatan yang diberikan oleh tenaga kesehatan. ${ }^{182}$

Sedangkan yang diteliti oleh penulis yaitu terkait bagaimana implementasi Undang-Undang Nomor 36 Tahun 2014 tentang Tenaga Kesehatan yakni tenaga medis, tenaga kebidanan, dan tenaga kefarmasian dalam pemberian pelayanan kesehatan pada pasien di Puskesmas Bajoe Kecamatan Tanete Riattang Timur Kabupaten Bone.

\section{METODE PENELITIAN}

1. Jenis dan Pendekatan Penelitian

Jenis penelitian yang digunakan penulis yaitu penelitian lapangan. Penelitian lapangan adalah penelitian yang langsung berhubungan dengan objek

\footnotetext{
${ }^{182}$ Maya Ruhtiani, "Perlindungan Hukum Pasien sebagai Konsumen Jasa dalam Pelayanan Kesehatan di Rumah Sakit Umum Daerah Tasikmalaya" (Universitas Jenderal Soedirman Fakultas Hukum), 2012. 
yang diteliti untuk memperoleh keterangan tentang implementasi UndangUndang Nomor 36 Tahun 2014 tentang Tenaga Kesehatan yakni dokter, bidan dan apoteker dalam memberikan pelayanan pada pasien. Berdasarkan permasalahan yang dikemukakan, maka penelitian ini menggunakan pendekatan penelitian yuridis normatif dan yuridis empiris.

a. Pendekatan yuridis normatif adalah pendekatan yang mengacu pada norma hukum yang terdapat dalam peraturan perundang-undangan dan putusan pengadilan serta norma yang hidup dan berkembang dalam masyarakat. ${ }^{183}$

Dalam hal ini penulis akan melihat undang-undang yang terkait dengan judul yang diteliti seperti Undang-Undang Nomor 36 Tahun 2014 tentang Tenaga Kesehatan, Undang-Undang Nomor 36 Tahun 2009 tentang Kesehatan, Undang-Undang Nomor 44 Tahun 2009 tentang Rumah Sakit yang membahas tentang perlindungan hak pasien.

b. Pendekatan yuridis empiris adalah penelitian yang dilakukan dengan pendekatan pada realitas hukum dalam masyarakat. Berdasarkan pernyataan tersebut maka penulis akan melihat realitas yang terjadi di Puskesmas Bajoe Kecamatan Tanete Riattang Timur Kabupaten Bone terkait pemberian pelayanan kesehatan oleh Tenaga kesehatan terhadap pasien. ${ }^{184}$

Berdasarkan penjelasan di atas, maka dalam penelitian, penulis menggunakan desain deskriptif kualitatif yaitu untuk menggambarkan bagaimana implementasi Undang-Undang Nomor 36 Tahun 2014 tentang Tenaga Kesehatan yakni dokter, bidan, dan apoteker dalam pemberian pelayanan pada pasien.

2. Lokasi Penelitian

${ }^{183}$ Zainuddin Ali, Metode Penelitian Hukum, Ed. 1, (Cet. 5; Jakarta: Sinar Grafika, 2014), h. 105.

${ }^{184}$ Syahruddin Nawawi, Penelitian Hukum Normatif Versus Penelitian Hukum Empiris (Cet. 2; Makassar: PT Umitoha Ukhuwah Grafika, 2014), h. 8. Jurnal Al-Dustur; VOLUME 2 NO 1, JUNI 2019 
Penelitian ini berlokasi di Puskesmas Bajoe Kecamatan Tanete Riattang Timur Kabupaten Bone. Di Kecamatan Tanete Riatang Timur merupakan daerah yang padat penduduknya sehingga memudahkan penulis bisa mengumpulkan informasi valid terkait implementasi Undang-Undang Nomor 36 Tahun 2014 tentang Tenaga Kesehatan dalam pemberian pelayanan kesehatan oleh tenaga kesehatan yakni dokter, bidan, dan apoteker.

Penulis melakukan penelitian di Puskesmas Bajoe Kecamatan Tanete Riattang Timur Kabupaten Bone dengan alasan bahwa adanya kewajiban yang harus dilakukan oleh tenaga kesehatan tersebut dalam memberikan pelayanan kepada pasien untuk memenuhi haknya akan tetapi belum sepenuhnya dijalankan.

3. Data dan Sumber Data

Data dan Sumber data dalam penelitian adalah subjek dari mana data diperoleh. ${ }^{185}$ Adapun yang menjadi sumber data dalam penelitian ini adalah sebagai berikut:

c. Data primer

Data primer dalam proses penelitian didefinisikan sebagai sekumpulan informasi yang diperoleh peneliti langsung dari lokasi penelitian melalui sumber pertama (responden atau informan, melalui wawancara) atau melalui hasil pengamatan yang dilakukan sendiri oleh peneliti. ${ }^{186}$ Data yang diperoleh langsung dari tenaga kesehatan yang bersangkutan dan pasien di Puskesmas Bajoe Kecamatan Tanete Riattang Timur Kabupaten Bone.

b. Data Sekunder

Data sekunder mencakup dokumen-dokumen resmi, buku-buku, hasil

\footnotetext{
${ }^{185}$ Suharsimi Arikunto, Prosedur Penelitian Suatu Pendekatan Praktek (Cet. XII; Jakarta: PT Rineka Cipta, 2002), h. 107.

${ }^{186}$ Nanang Marton, Metode Penelitian Sosial (Konsep-konsep Kunci), Ed. 1 (Cet. 1; Jakarta: PT. RajaGrafindo Persada, 2015), h. 65.

Jurnal Al-Dustur; VOLUME 2 NO 1, JUNI 2019
} 
penelitian yang berwujud laporan. ${ }^{187}$ Dalam penelitian ini menggunakan data sekunder sebagai berikut:

1) Bahan hukum primer:

a) Undang-Undang Dasar 1945

b) Undang-Undang Nomor 36 Tahun 2014 tentang Tenaga Kesehatan

c) Undang-Undang Nomor 36 Tahun 2009 tentang Kesehatan

d) Undang-Undang Nomor 29 Tahun 2004 tentang Praktik Kedokteran

e) Undang-Undang Nomor 44 Tahun 2009 tentang Rumah Sakit

f) Peraturan Pemerintah Nomor 32 Tahun 1996 tentang Tenaga Kesehatan

g) Peraturan Menteri Kesehatan Republik Indonesia Nomor 1464/MENKES/PER/X/2010 tentang Izin dan Penyelenggaraan Praktik Bidan.

h) Peraturan Menteri Kesehatan Republik Indonesia Nomor 363/MENKES/PER/IX/1980 tentang Wewenang Bidan.

i) Peraturan Menteri Kesehatan Republik Indonesia Nomor 9 Tahun 2017 tentang Apotek.

2) Bahan hukum sekunder:

a) Buku-buku yang terkait dengan judul

b) Literatur yang terkait dengan judul

c) Penelitian terdahulu

4. Instrumen Penelitian

Instrumen penelitian merupakan alat yang digunakan dalam pengumpulan data. Dalam penelitian ini akan menggunakan alat yaitu daftar pertanyaan, recorder dari handphone dibantu alat tulis lainnya, kemudian dibuatkan transkripnya dengan mengubah hasil wawancara tersebut dari bentuk

\footnotetext{
${ }^{187}$ Amiruddin dan Zainal Asikin, Pengantar Metode Penelitian Hukum (Cet. 1; Jakarta: PT. Grafindo Persada, 2004), h. 30.

Jurnal Al-Dustur; VOLUME 2 NO 1, JUNI 2019
} 
rekaman menjadi bentuk tertulis. ${ }^{188}$

\section{Teknik Pengumpulan Data}

Tekhnik yang digunakan untuk mengumpulkan data dalam penelitian ini dengan teknik wawancara dan observasi (pengamatan).

a. Wawancara adalah percakapan yang dilakukan dengan berhadapan secara langsung tetapi dapat juga diberikan daftar pertanyaan dahulu untuk dijawab pada kesempatan lain. Percakapan itu dilakukan oleh dua pihak, yaitu pewawancara (interviewer) yang mengajukan pertanyaan dan terwawancara (interviewer) yang memberikan jawaban atas pertanyaan. Wawancara yang dilakukan bertujuan untuk mendapatkan keterangan atau penjelasan langsung dari narasumber terkait dengan obyek penelitian. Dalam hal ini yang akan diwawancarai yaitu tenaga kesehatan yang bersangkutan dan pasien.

b. Observasi (pengamatan) adalah teknik dalam pengumpulan data dengan cara melakukan penelitian terhadap objek yang akan diteliti baik secara langsung maupun tidak langsung. ${ }^{189}$ Dalam hal ini yang di amati oleh penulis yaitu dengan melakukan pengamatan langsung secara sistematis di Puskesmas Bajoe Kecamatan Tanete Riattang Timur Kabupaten Bone.

\section{Teknik Analisis Data}

Dalam menganalisis data, penulis menggunakan analisis data secara kualitatif. Analisis data kualitatif adalah penelitian yang berupaya menganalisis kehidupan sosial dengan menggambarkan dunia sosial dari sudut pandang atau interprestasi individu (informan) dalam latar alamiah. Adapun tahapannya sebagai berikut:

\footnotetext{
${ }^{188}$ Muhammad Teguh, Metodologi Penelitian Ekonomi Teori dan Aplikasi, Ed.1 (Cet.3; Jakarta: PT.RajaGrafindo Persada, 2005), h. 137.

${ }^{189}$ Lexy J. Moleong, Metodologi Penelitian Kualitatif Ed. Revisi, (Cet. 22; Bandung: PT Remaja Rosda Karya, 20 04), h. 189.

Jurnal Al-Dustur; VOLUME 2 NO 1, JUNI 2019
} 
a. Pengumpulan data lapangan yakni dengan mengumpulakan data yang ditemukan di lapangan yang merupakan data kasar.

b. Reduksi data adalah proses memilih atau menyederhanakan, mengabstraksikan dan mentranspormasikan data kasar yang baru dari lapangan.

c. Penyajian data merupakan sekumpulan informasi yang tersusun secara sistematis yang kemungkinan adanya penarikan kesimpulan.

d. Verifikasi data yakni penarikan kesimpulan akhir penelitian. ${ }^{190}$

\section{HASIL PENELITIAN DAN PEMBAHASAN}

\section{Praktek Pemberian Pelayanan Kesehatan oleh Dokter terhadap Pasien}

Dokter adalah seseorang yang karena keilmuannya dan keterampilannya berusaha menyembuhkan orang-orang yang sakit, akan tetapi tidak semua orang yang menyembuhkan penyakit disebut dokter. Untuk menjadi dokter diperlukan pendidikan dan pelatihan khusus sehingga mempunyai gelar dalam bidang kedokteran. Menjadi seorang dokter mempunyai tugas utama yaitu untuk menyelesaikan semua masalah kesehatan yang dihadapi pasien tanpa memandang jenis penyakit, golongan usia, dan jenis kelamin.

Pasien sangat menginginkan pelayanan kesehatan yang layak terhadapnya, maka dari itu sebagai seorang dokter harus memberikan pelayanan yang baik kepada pasiennya sehingga pasien merasa sangat dihormati ketika diperiksa.

Menurut dr. A. Resky Soraya mengatakan bahwa terkait dengan pemberian pelayanan kesehatan terhadap pasien di puskesmas Kecamatan Tanete Riattang Timur Kabupaten Bone sudah berjalan dengan baik dan benar, di antaranya mengenai pemberian informasi tata tertib atau peraturan yang ada di puskesmas, meminta persetujuan pasien sebelum dilakukannya sebuah tindakan, diperbolehkan ditemani

\footnotetext{
190 Muhammad Tholchah Hasan, dkk, Metode Penelitian Kualitatif Tinjauan Teoritis dan Praktis, (Cet. 3; Surabaya: Visipress Media, 2009), h. 182-183. 
oleh rekan, saudara, atau kerabatnya selama dalam pemeriksaan di puskesmas, menjaga rahasia pasien terkait masalah penyakit yang dideritanya, merujuk pasien ke dokter lain yang mempunyai keahlian atau kemampuan yang lebih baik ketika dokter tersebut tidak mampu melakukan pemeriksaan atau pengobatan, membuat dan menyimpan catatan atau dokumen pemeriksaan asuhan dan tindakan yang dilakukan kepada pasien, memperlakukan sama semua pasien, serta pasien diberikan jaminan keamanan, keselamatan, dan kenyamanan selama dalam pemeriksaan di puskesmas. ${ }^{191}$

\section{Pemberian Pelayanan Kesehatan oleh Bidan terhadap Pasien}

Bidan adalah seseorang yang telah mengikuti program pendidikan bidan yang diakui di negaranya dan telah lulus dari pendidikannya, serta memenuhi kualifikasi untuk didaftarkan dan atau memiliki izin yang sah untuk melakukan praktik bidan. Pelayanan kebidanan adalah seluruh tugas dan kewenangan yang menjadi tanggungjawabnya dalam meningkatkan pelayanan kesehatan ibu, pelayanan kesehatan anak, serta pelayanan kesehatan reproduksi perempuan dan keluarga berencana.

Menurut Nuraeni, S.ST selaku bidan di puskesmas Kecamatan tanete Riattang Timur Kabupaten Bone mengatakan bahwa pemberian pelayanan kesehatan yang ada di puskesmas tersebut sudah berjalan dengan baik, di antaranya mengenai tata tertib dan peraturan yang berlaku di Puskesmas tersebut sudah diberitahukan kepada pasien, terkait persetujuan pasien sebelum dilakukan pemeriksaan maka diperbolehkannya ditemani oleh rekan, saudara, atau kerabatnya selama dalam pemeriksaan agar pasien dan keluarga menyepakati amanat persalinan di STIKER P4K, membuat dan menyimpan catatan atau dokumen pemeriksaan asuhan dan tindakan yang dilakukan kepada pasien, merujuk pasien kebidan lain yang mempunyai keahlian atau

${ }^{191}$ dr. A. Resky Soraya, Dokter Puskesmas Bajoe Kecamatan Tanete Riattang Timur Kabupaten Bone wawancara oleh penulis di Puskesmas Bajoe Kecamatan Tanete Riattang Timur Kabupaten Bone, 25 September 2017. 
kemampuan yang lebih baik ketika bidan tersebut tidak mampu menangani pasien tepat waktu karena untuk mencegah kemungkinan erjadinya komplikasi dan menangani secara cepat dan tepat, menyimpan rahasia pasien baik mengenai penyakit yang dideritanya maupun terkait dengan kematiannya, serta pasien diberikan jaminan keamanan, keselamatan, dan kenyamanan selama dalam pemeriksaan. ${ }^{192}$

Nuraeni pun menyatakan bahwa terkait diskriminasi yang dialami pasien tidak pernah terjadi, namun apabila ada keluhan yang dialami oleh pasien terkait pelayanan yang diterima maka segera dilakukan perbaikan dan pasien dapat mengadukannya melalui kotak saran. Pernyataan tersebut sependapat dengan rekan kerjanya yakni Iva Andriani dan Sri Rahmayani.

\section{Pemberian Pelayanan Kesehatan oleh Apoteker terhadap Pasien}

Apoteker adalah gelar profesi bagi seseorang yang telah mengucapkan sumpah jabatan apoteker serta yang ahli dalam ilmu obat-obatan dan berwenang membuat obat untuk dijual. Apoteker/ asisten apoteker sebagai tenaga farmasi dituntut untuk meningkatakan pengetahuan, keterampilan perilaku agar dapat berinteraksi langsung dengan pasien.

Menurut Anita Indrawaty S. Farm selaku asisten apotekar di Puskesmas kecamatan Tanete Riattang Timur Kabupaten Bone yang mengatakan bahwa pelayanan kesehatan yang diberikan oleh pasien sudah berjalan dengan baik yakni terkait pemberian informasi menegenai tata tertib atau peraturan yang ada di Puskesmas, pasien diperbolehkan ditemani oleh rekan, saudara, atau kerabatnya selama dalam pemberian pelayanan obat di puskesmas karena untuk mengantisipasi jika ada pasien yang lansia atau yang kurang pendengarannya, pasien diperbolehkan meminta salinan resep kepada apoteker kecuali untuk resep obat keras/ narkotik karena harus melalui dokter namun jika ada penulisan resep yang membuat pasien keliru maka segera

\footnotetext{
${ }^{192}$ Nuraeni, S.ST, Bidan Puskesmas Bajoe Kecamatan Tanete Riattang Timur Kabupaten Bone wawancara oleh penulis di Puskesmas Bajoe Kecamatan Tanete Riattang Timur Kabupaten Bone, 25 September 2017. 
menghadap kedokter untuk dikonfirmasi, serta jika ada keluhan yang dialami oleh pasien maka diadukan melalui kotak saran dan segeralah dilakukan perbaikan. ${ }^{193}$

Dari ketiga penjelasan tenaga kesehatan tersebut mempunyai maksud dan tujuan yang sama khususnya dalam pemberian pelayanan terhadap pasien di Puskesmas Kecamatan Tanete Riattang Timur Kabupaten Bone. Adapun yang menjadi harapan tenaga kesehatan terkait penerapan Undang-Undang Nomor 36 Tahun 2014 tentang Tenaga Kesehatan yaitu bahwa diharapkan setiap tenaga kesehatan mempunyai/ wajib memiliki Surat Izin Kerja (SIK) yang akan melindungi tenaga kesehatan dalam bekerja.

\section{PENUTUP}

Setelah menjelaskan secara panjang lebar maka dapat ditarik suatu kesimpulan bahwa berdasarkanUndang-UndangNomor 36 Tahun 2014 tentangTenaga Kesehatan yang merupakan suatu aturan yang berisi kewajibanbagi tenaga kesehatan yakni dokter, bidan, dan apoteker untuk memenuhi seluruh hak pasien dalam memperoleh pelayanan kesehatan yang optimal sesuai dengan kebutuhannya, baik pelayanan kesehatan dasar maupun rujukan, tanpa membedakan status sosial. Selain itu, tenaga kesehatan tersebut mempunyai kewajiban untuk dapat mengendalikan dan menyempurnakan pelayanan yang disediakan kepada pasien.

Adapun praktek pemberian pelayanan kesehatan pada pasien bahwa tenaga kesehatan memiliki peranan penting untuk meningkatkan kualitas pelayanan kesehatan yang maksimal kepada pasien agar pasien mampu untuk meningkatkan kesadaran, kemauan, dan kemampuan hidup sehat sehingga akan terwujud derajat kesehatan yang

${ }^{193}$ Anita Indrawaty S. Farm, Asisten Apoteker Puskesmas Bajoe Kecamatan Tanete Riattang Timur Kabupaten Bone wawancara oleh penulis di Puskesmas Bajoe Kecamatan Tanete Riattang Timur Kabupaten Bone, 25 September 2017. 
setinggi-tingginya sebagai investasi bagi pembangunan sumberdaya manusia yang produktif secara social dan ekonomi. Selainitu, penyelenggaraan upaya kesehatan harus dilakukan oleh tenaga kesehatan yang bertanggungjawab, yang memiliki etik dan moral yang tinggi, keahlian, dankewenangan yang secara terus menerus harus di tingkatkan mutunya.Maka darii tu, adanya pembenaran hokum yaitu diperkenankannya melakukan pelayanan kepada pasien dan apabila hal itu dilakukan olehtenaga kesehatan lain yang memang bukan haknya dapat digolongkan sebagai tindakan administratif.

\section{REFERENSI}

Achmadi, Umar Fahmi. Kesehatan Masyarakat (Teori dan Aplikasi). Ed.1. Cet.1; Jakarta: Rajawali Pers, 2013.

Ali, Zainuddin. Metode Penelitian Hukum. Ed. 1. Cet. 5; Jakarta: Sinar Grafika, 2014.

Amiruddin dan Zainal Asikin. Pengantar Metode Penelitian Hukum. Cet.1; Jakarta: PT. Grafindo Persada, 2004.

Arikunto, Suharsimi. Prosedur Penelitian Suatu Pendekatan Praktek. Cet. XII; Jakarta: PT Rineka Cipta, 2002.

Departemen Agama RI. Al-Qur'an dan Tafsirnya. Jilid V. Cet. III; Jakarta: Lembaga Percetakan al-Qur'an Departemen Agama, 2009.

Harapan, Tim Pustaka Agung. Kamus Ilmiah Populer. Surabaya; Cv Pustaka Agung Harapan.

Hartini, Yustina Sri dan Sulasmono. Apotek Edisi Revisi. Cet. 3; Yogyakarta: Universitas Sanata Dharma, 2010.

Hasan, Muhammad tholchah, dkk. Metode Penelitian Kualitatif Tinjauan Teoritis dan Praktis. Cet. 3; Surabaya: Visipress Media, 2009.

Hasyim, Masruroh, Dkk. Buku Pedoman Keperawatan. Cet. 1; Yogyakarta: Indoliterasi, 2014.

HR. Ahmad, ath-Thabrani, ad-Daruqutni. Hadist ini dihasankan oleh al-Albanidi dalam Shahihul Jami' no: 3289.

Junaidi, Eddi. Mediasi dalam Penyelesaian Sengketa Medik. Ed. 1. Cet. 1; Jakarta: Rajawali Pers, 2011.

Koentjoro, Tjahjono. Regulasi Kesehatan di Indonesia Edisi Revisi. Yogyakarta: CV Andi Offset, 2011.

Jurnal Al-Dustur; VOLUME 2 NO 1, JUNI 2019 
Marton, Nanang. Metode Penelitian Sosial (Konsep-konsep Kunci). Ed. 1. Cet.1; Jakarta: PT. RajaGrafindo Persada, 2015.

Moleong, Lexy J. Metodologi Penelitian Kualitatif Edisi Revisi. Cet. 22; Bandung: PT Remaja Rosdakarya, 2004.

Nawawi, Syahruddin. Penelitian Hukum Normatif Versus Penelitian Hukum Empiris. Cet. 2; Makassar: PT Umitoha Ukhuwah Grafika, 2014.

Pontoh, Idham. Dasar-Dasar Ilmu Kesehatan Masyarakat. Edisi Asli. Jakarta: In Media, 2013.

Saam, Zulfan dan Sri Wahyuni. Psikologi Keperawatan. Ed. 1. Cet. 1; Jakarta: Rajawali Pers, 2013.

Sadi, Muhamad. Etika Hukum Kesehatan. Ed. 1. Cet. 1; Jakarta: Prenadamedia Group, 2015.

Teguh, Muhammad. Metodologi Penelitian Ekonomi Teori dan Aplikasi. Ed.1. Cet. 3; Jakarta: PT.RajaGrafindo Persada, 2005.

Thamrin, Husni. Hukum Pelayanan Publik di Indonesia. Cet. 2; Yogyakarta: Aswaja Pressindo, 2013.

Trihartono. The Doctor: Catatan Hati Seorang Dokter. Cet. 2; Yogyakarya: Pustaka Anggrek, 2010.

Wahidin. Pendidikan Kewarganegaraan. [t.t.]: In Media, 2015.

Wibowo, Adik. Kesehatan Masyarakat Indonesia. Ed. 1. Cet. 1; Jakarta: Rajawali Pers, 2014.

Wiradharma, Danny. Penuntun Kuliah Hukum Kedokteran. Ed. 1. Cet 1; Jakarta: Anggota IKAPI, 2010. 